\title{
Risiko Usahatani Bawang Merah di Kabupaten Bantul
}

\author{
Marfin Lawalata* \\ Dwidjono Hadi Darwanto** \\ Slamet Hartono** \\ *Jurusan Agribisnis, Fakultas Pertanian, Universitas Pattimura \\ **Fakultas Pertanian UGM, Kampus Bulaksumur - Yogyakarta \\ Email: marfin.lawalata@faperta.unpatti.ac.id
}

\begin{abstract}
Abstrak
Penelitian ini bertujuan mengukur risiko produksi dan risiko pendapatan usahatani bawang merah di Kabupaten Bantul serta faktor-faktor yang mempengaruhinya, dan mengetahui perilaku petani terhadap risiko usahatani bawang merah di Kabupaten Bantul dan faktor-faktor yang mempengaruhinya. Penelitian dilakukan terhadap 60 petani bawang merah di Kabupaten Bantul. Metode penelitian yang digunakan untuk mengukur risiko produksi dan pendapatan menggunakan nilai koefisien variasi (CV), dan perilaku petani terhadap risiko menggunakan metode Moscardi dan de Janvry. Selanjutnya menggunakan analisis regresi Ordinary Least Squares (OLS) untuk menganalisis faktor-faktor yang mempengaruhi perilaku petani terhadap risiko usahatani bawang merah di Kabupaten Bantul. Hasil penelitian menunjukkan bahwa risiko produksi sebesar $0,8518(85,18 \%)$ dan risiko pendapatan sebesar 1,2416 $(124,16$ \%). Petani bawang merah di Kabupaten Bantul mayoritas memiliki perilaku menolak risiko sebanyak 44 petani $(73,33 \%)$ walaupun usahatani bawang merah berisiko. Umur petani, pendidikan, pendapatan usahatani bawang merah dan pendapatan luar usahatani bawang merah siginifikan dan mempengaruhi perilaku petani terhadap risiko.
\end{abstract}

\section{Kata Kunci: Bawang merah, Ordinary Least Square (OLS), perilaku terhadap risiko, risiko}

\begin{abstract}
This study aims: to measure the production and income risks of red onion farming in Bantul regency and to investigate the behavior of farmers toward the risk of red onion farming in Bantul regency and its determinant factors. The study was conducted for 60 red onion farmers in Bantul regency. Furthermore, coefficient of variation (CV) was applied to quantify the risk of production and income. Then, to measure the behavior of farmers toward the risk it uses Moscardi and de Janvry method. It is followed by using the analysis of Ordinary Least Square regression (OLS) to analyze the factors which affects the Behavior towards risk of onion farming in Bantul regency. The level of production risk is 0.8518 (85.18\%) and the income risk is 1.2416 (124.16\%).The results of research showed most of the Red onion farmers in Bantul regency (44 farmers or 73.33\%) are risk averter although they do risky onion farming. Age farmers, education, income of red onion farming, and income of non-red onion farming significantly influence the behavior of farmers to risk.
\end{abstract}

Key Words : Shallots, Ordinary Least Square (OLS), behavior towards risk, risk 


\begin{tabular}{llr}
\multicolumn{2}{c}{ Pengembangan } & komoditas \\
usahatani bernilai tinggi & guna \\
meningkatkan pendapatan & petani \\
merupakan hal penting & dalam \\
meningkatkan kemampuan & sektor
\end{tabular}
pertanian. Hal ini dikarenakan kemampuan sektor pertanian untuk memberikan kontribusi secara langsung terhadap pertumbuhan ekonomi dan kesejahteraan rumah tangga tani tergantung pada tingkat pendapatan usahatani dan surplus yang dihasilkan oleh sektor itu sendiri. Komoditas hortikultura merupakan komoditas potensial yang mempunyai nilai ekonomi tinggi dan memiliki potensi untuk terus dikembangkan.

Pengembangan usahatani dengan komoditas hortikultura bernilai tinggi diantaranya dengan mengembangkan usahatani bawang merah untuk meningkatkan pendapatan petani.

Bawang merah sudah lama dikembangkan di Kabupaten Bantul, ragam penggunaan pola tanam dan orientasi perdagangan yang digunakan turut berperan terhadap keberhasilan pengembangan bawang merah di Bantul. Pola tanam yang sering digunakanan masyarakat Bantul adalah monokultur dan tumpang gilir sedangkan orientasi perdagangannya untuk memenuhi kebutuhan masyarakat Bantul (substitusi Impor) dan di luar daerah (perdagangan antar daerah), dengan pemilihan sistem usahatani dan orientasi perdagangan bawang merah yang tepat dapat meningkatkan produktivitas di dalam negeri dan pendapatan petani.

Peningkatan konsumsi bawang merah dalam negeri harus diimbangi dengan peningkatan produksi dalam negeri, baik kuantitas maupun kualitas, dengan cara intesifikasi maupun ekstensifikasi. Kabupaten Bantul merupakan salah satu daerah sentra penghasil bawang merah di Daerah Istimewa Yogyakarta dan produksinya mengalami perubahan dari tahun ke tahun hal ini dikarenakan perubahan luas areal tanam dan produktivitas tanaman tersebut.

Berdasarkan hasil wawancara, dari usahatani bawang merah petani memperoleh pendapatan terendah sebesar Rp. 312.375 dengan luas lahan usahatani $200 \mathrm{~m}^{2}$ dan pendapatan tertinggi Rp 32.491.916.67 dengan luas lahan $6000 \mathrm{~m}^{2}$ pada musim tanam pertama (MT I). Walaupun pendapatan usahatani bawang merah tinggi namun risiko yang dihadapi juga tinggi, tingginya risiko produksi maupun risiko harga akan berpengaruh terhadap pendapatan petani. Menurut (Debertin, 1986) pertanian dicirikan dengan kondisi yang penuh risiko dan ketidakpastian, hal ini dikarenakan kegiatan pertanian rentan terhadap perubahan iklim, serangan hama dan penyakit serta fluktuasi harga produk pertanian di pasar. Risiko berpengaruh terhadap pengambilan keputusan atau perilaku petani (Soekartawi, 1986). Petani yang takut terhadap risiko produksi mengalokasikan input yang lebih sedikit dibandingkan dengan petani yang menyukai risiko. Dengan kata lain semakin berani petani dalam menghadapi risiko maka input yang dialokasikan semakin besar (Doll dan Orazem,1978). Keenganan terhadap risiko dipengaruhi oleh karakteristik individu petani (Biswanger, 1990). Menurut Ellis (2003) mengemukakan bahwa sebagian besar petani kecil 
(gurem) di negara-negara berkembang berperilaku menghindari risiko (risk averter). Perilaku petani menghindari risiko menyebabkan alokasi penggunaan input tidak efisien, sehingga pada akhirnya berpengaruh terhadap tingkat produktivitas usahatani.

Just dan Pope mengemukakan bahwa hampir setiap proses produksi terutama produksi pertanian, risiko produksi memainkan peranan yang sangat penting dalam keputusan alokasi penggunaan input, yang akhirnya berpengaruh pada tingkat produktivitas yang dicapai. Analisis risiko produksi yang dikembangkan oleh Just dan Pope sangat penting untuk kegiatan manajemen risiko produksi, yaitu untuk memutuskan apakah input produksi tertentu yang digunakan dalam kegiatan usahatani harus ditambah atau dikurangi.

Petani bawang merah seperti halnya petani yang lain sering menghadapi permasalahan diantaranya berisiko tinggi, produktivitas rendah, dan juga tidak efisien. Rendahnya tingkat produktivitas menunjukan bahwa pengelolaan usahatani bawang merah belum efisien, hal ini ditambah pula dengan kenyataan bahwa komoditas bawang merah merupakan tanaman berisiko tinggi. Kondisi alam yang tidak bersahabat akan meningkatkan risiko usahatani seperti gagal panen karena banjir, kekeringan maupun serangan hama dan penyakit. Risiko ini masih ditambah lagi dengan fluktuasi harga dan struktur pasar yang merugikan dan menyebabkan petani selalu menghindari risiko (Anonim, 2005).
Tanpa adanya upaya untuk memacu produksi bawang merah dalam negeri, maka volume impor bawang merah mempunyai potensi untuk terus meningkat mengingat peningkatan kebutuhan dalam negeri lebih cepat dari peningkatan produksi. Sebagian besar petani di Kabupaten Bantul, khususnya di bagian selatan mengusahakan tanaman bawang merah sebagai komoditi utama sepanjang tahun. Tanaman ini membutuhkan dana yang lebih besar untuk biaya produksi dibandingkan dengan mengusahakan tanaman pangan yang diusahakan petani pada umumnya. Kemungkinan gagal panen cukup tinggi, disamping harga produknya berfluktuatif sepanjang tahun. Keberanian petani menanggung risiko produksi dan harga sangat menarik untuk diteliti.

Keberhasilan usahatani bawang merah yang dilakukan oleh seorang petani pada dasarnya ditentukan oleh besarnya pendapatan, risiko dan juga oleh tingkat efisiensi yang akan dihadapi. Besar kecilnya pendapatan dipengaruhi oleh tingkat produksi, harga produksi dan biaya yang akan dikeluarkan untuk proses produksi, di samping itu besar kecilnya pendapatan juga dipengaruhi oleh risiko yang akan dihadapi. Tingkat produksi, harga produksi dan biaya yang akan dikeluarkan dipengaruhi oleh penggunaan teknologi, fluktuasi harga, kebijakan pemerintah, finansial, perilaku individu petani dan iklim. Risiko kegagalan dalam usahatani bersumber pada penggunaan teknologi baru, harga produksi pertanian, finansial, kebijakan pemerintah dan perilaku individu petani dalam berhubungan dengan pihak luar. 
Dalam menghadapi risiko, petani dapat berperilaku menyukai risiko (risk lover), menolak risiko (risk averter) atau netral terhadap risiko (risk neutral). Perilaku petani terhadap risiko sangat dipengaruhi oleh karakteristik individu petani seperti luas lahan, umur, pendidikan, pengalaman, jumlah anggota keluarga, frekuensi kegagalan dan pendapatan petani. Dalam kenyataannya perilaku petani terhadap risiko berpengaruh terhadap tingkat efisiensi relatif usahatani bawang merah. Bagaimana perilaku petani terhadap risiko usahatani bawang merah dan faktor-faktor yang mempengaruhi perilaku petani terhadap risiko ? Menganalisis perilaku petani terhadap risiko usahatani bawang merah serta faktor-faktor yang mempengaruhi perilaku petani terhadap risiko.

\section{METODE PENELITIAN}

Analisis risiko usahatani bawang merah meliputi risiko produksi dan risiko pendapatan serta. Analisis risiko usahatani bawang merah meliputi risiko produksi dan risiko pendapatan dianilisis dengan menentukan besarnya koefisien variasi (CV). Cara ini dilakukan dengan menggunakan data produksi, biaya, harga produk dan pendapatan yang diperoleh dari usahatani bawang merah. Koefisien variasi merupakan ukuran risiko relatif yang diperoleh dengan membagi standar deviasi dengan nilai rata-rata yang diharapkan (Papas dan Hirschey, 1995). Hasil penelitian Kimbal (Chen et al, 1999) menunjukkan bahwa risiko pendapatan dapat diukur dengan besarnya varians dan standar deviasi. Koefisien variasi secara matematis bisa dituliskan sebagai berikut :

$$
\begin{aligned}
& K V=\frac{\sigma}{\bar{Y}} \\
& \sigma=\sqrt{\frac{\sum y^{2}}{n}} \\
& y=Y-\bar{Y}
\end{aligned}
$$

Keterangan :

$\mathrm{KV}=$ koefisien variasi produksi

$\sigma=$ standar deviasi produksi (varian)

$$
\begin{aligned}
\bar{Y} & =\text { rata-rata produksi } \\
\mathrm{n} & =\text { jumlah sampel }
\end{aligned}
$$

Besarnya nilai koefisien variasi menunjukan besarnya risiko relatif usahatani bawang merah. Kalau nilai koevisien variasi yang kecil menunjukan variabilitas nilai rata-rata pada usahatani tersebut rendah. Hal ini menggambarkan risiko yang akan dihadapi petani rataratanya kecil. Sebaliknya nilai koefisien variasi yang besar menunjukan variabilitas nilai rata-rata pada usahatani bawang merah tersebut tinggi dan menggambarkan risiko yang akan dihadapi petani rata-ratanya besar.

Terdapat suatu hipotesis petani bawang merah mempunyai perilaku berani menanggung risiko (risk lover) terhadap penggunaan input. Untuk menguji hipotesis tersebut digunakan pendekatan model fungsi produksi Cobb Douglas kemudian dianalisis dengan OLS, pilihan penggunaan input menurut Moscardi dan de Janvry (1977) dan (Olarinde et al, 2007) adalah :

$$
P_{y} f_{i} \frac{\mu_{y}}{X_{i}}=\frac{P_{x i}}{1-\theta K(S)}
$$

Maka model persamaan tersebut dapat diubah menjadi :

$$
K(S)=\frac{1}{\theta}\left(1-\frac{P_{i} X_{i}}{P_{y} f_{i} \mu_{y}}\right)
$$

Keterangan : 

$E(Y)=$ expected produksi $\left(\mu_{y}=\right.$ produksi rata-rata)
$\theta=$ koefisien variasi dari produksi $\left(\theta=\delta_{y} / \mu_{y}\right)$ dimana $\delta_{\gamma}=$ standar deviasi dari produksi dan $\mu_{y}=$ produksi rata- rata.
$P_{y} \quad=$ harga produk
$f_{i} \quad=$ elastisitas produksi dari input ke-i (elastisitas dari input yang paling signifikan dan mempunyai kontribusi terbesar).
$X_{i}=$ jumlah input ke $-\mathrm{i}$ (jumlah input yang paling signifikan dan mempunyai kontribusi terbesar pada masing-masing responden).
$P_{x i}=$ harga input ke $-\mathrm{i}$ ( harga input yang paling signifikan dan mempunyai kontribusi terbesar pada masing-masing responden).

$K(S)=$ pengukuran parameter keengganan terhadap risiko, $S$ adalah variable yang mempresentasikan

karakteristik petani.

Persamaan tersebut memberikan alat ukur untuk menghitung penolakan risiko $K(S)$ yang diturunkan untuk masingmasing petani pada fungsi produksi, koefisien variasi dari hasil, produksi dan faktor harga serta tingkat penggunaan input yang diamati (Olarinde et al, 2007).

Lebih lanjut Moscardi dan de Janvry (1977), parameter penolakan risiko $K(S)$ digunakan untuk mengklasifikasikan petani menjadi 3 kelompok yaitu :

- Mengambil risiko (risk lover) atau risiko rendah $(0<K(S)<0,4)$
- Mengambil posisi netral (risk neutral) atau risiko menengah $(0,4<K(S)<$ 1,2)

- Menolak risiko (risk averter) atau resiko tinggi $(1,2<K(S)<2,0)$

Sedangkan hipotesis yang menyatakan faktor-faktor yang mempengaruhi perilaku petani terhadap risiko adalah luas lahan, umur petani, pendidikan petani, pengalaman berusahatani bawang merah, jumlah tanggungan keluarga, pendapatan usahatani bawang merah, dan pendapatan luar usahatani bawang merah.

Untuk menguji hipotesis tersebut dilakukan analisis regresi linear dari model berikut ini :

$$
\begin{aligned}
K(S)= & \alpha_{0} L_{-} L A H A N{ }^{\alpha 1} U_{-} \text {PETANI }{ }^{\alpha 2} \text { PENDK }{ }^{\alpha 3} \\
& P_{-} \text {USTAN }{ }^{3} \quad \text { JMLTGKLG } \alpha 5 \\
& \text { PENDUSTAN }{ }^{\alpha} \text { PENLUSTAN } \alpha 7 \\
& \text { Dalam bentuk In dapat dituliskan }
\end{aligned}
$$
sebagai berikut :

$\ln K(S)=\alpha_{0}+\alpha_{1} \ln L_{-} L A H A N+\alpha_{2} \ln$ $U_{-} P E T A N I+\alpha_{3} \ln$ PENDK + $\alpha_{4} \ln P_{-} U S T A N+\alpha_{5} \ln$ JMLTGKLG $+\alpha_{6} \ln$ PENDUSTAN $+\alpha_{7} \ln$ PENLUSTAN

Keterangan :

$K(S)=$ parameter keengganan terhadap risiko, $S$ adalah variabel yang mempresentasikan karakteristik petani.

$L_{-} L A H A N=$ luas lahan (ha)

U_PETANI = umur petani (thn)

PENDK = pendidikan petani (thn)

$P_{-}$USTAN = pengalaman berusahatani (thn)

JMLTGKLG = jumlah tanggungan keluarga (orang)

PENDUSTAN = pendapatan usahatani bawang merah (Rp/thn) 


\begin{tabular}{|c|c|}
\hline \multicolumn{2}{|c|}{ PENDLUSTAN=pendapatan } \\
\hline & $\begin{array}{l}\text { usahatani bawang mera } \\
\text { (Rp/thn) }\end{array}$ \\
\hline$\alpha_{0}$ & $=$ intersep \\
\hline$\alpha_{1}$ & $\begin{array}{l}=\text { koefisien regresi lu } \\
\text { lahan }\end{array}$ \\
\hline$\alpha_{2}$ & $\begin{array}{l}=\text { koefisien regresi um } \\
\text { petani }\end{array}$ \\
\hline$\alpha_{3}$ & $\begin{array}{l}=\quad \text { koefisien } \text { regre } \\
\text { pendidikan petani }\end{array}$ \\
\hline$\alpha_{4}$ & $\begin{array}{l}=\quad \text { koefisien reg } \\
\text { pengalaman berusahat }\end{array}$ \\
\hline$\alpha_{5}$ & $\begin{array}{l}=\quad \text { koefisien regresi jum } \\
\text { tanggungan keluarga }\end{array}$ \\
\hline$\alpha_{6}$ & $\begin{array}{l}=\text { koefisien regresi pendapa } \\
\text { usahatani bawang merah }\end{array}$ \\
\hline$\alpha_{7}$ & $\begin{array}{l}=\text { koefisien regresi pendap } \\
\text { luar usahatani bawang merah }\end{array}$ \\
\hline
\end{tabular}

Hipotesis dari model diatas :

$H_{0}: \alpha_{i}=0$,artinya tidak ada pengaruh variabel independen ke-i terhadap variabel

dependen (keenganan terhadap risiko)

$H_{a}: \alpha_{i} \neq 0$,artinya ada pengaruh variabel independen ke-i terhadap variabel dependen (keengganan terhadap risiko)

Pengujian model analisis tersebut di atas dengan menggunakan ordinary least square (OLS) yang dilakukan melalui dua tahap, yaitu (1) pengujian terhadap asumsi-asumsi klasik, dan 2) pengujian terhadap kesesuaian model (Pindyck and Rubinfeld, 1991; Maddala, 1992; Green, 1993; dan Gujarati, 1997). Pengujian asumsi klasik yang dilakukan dalam penelitian ini adalah uji multikolinearitas dan heteroskedastisitas, hal ini karena data yang digunakan berupa data satu titik waktu atau cross-section (Gujarati,
1997). Jika model yang dianalisis tidak terdapat gangguan asumsi klasik, maka model yang digunakan untuk mengidentifikasi adalah hasil analisis ordinary least square (OLS). Jika terdapat gangguan multikolinearitas dan heteroskedastisitas, maka model yang sudah diperbaiki sehingga terbebas dari kedua gangguan tersebut.

\section{HASIL DAN PEMBAHASAN}

Risiko usahatani bawang merah di Kabupaten Bantul terdiri dari risiko produksi dan risiko pendapatan. Pada penelitian ini yang dikaji hanya risiko produksi dan risiko pendapatan, sedangkan risiko biaya tidak dikaji. Metode yang digunakan untuk mengkaji kedua jenis risiko ini dengan analisis koefisien variasi (CV). Analisis ini merupakan perbandingan antara nilai standar deviasi dengan nilai rata - rata sehingga dapat diketahui besarnya risiko relatif dari produksi dan pendapatan pada usahatani bawang merah. Nilai koefisien variasi (CV) yang kecil menunjukan variabilitas nilai rata-rata pada risiko tersebut rendah. Hal in menunjukan risiko yang dihadapi dalam memperoleh hasil produksi dan pendapatan kecil. Dan sebaliknya, jika nilai koefisien variasi (CV) yang lebih besar menunjukan variabilitas nilai ratarata pada risiko tersebut tinggi. Ini menunjukan bahwa risiko yang dihadapi dalam memperoleh hasil produksi dan pendapatan besar. Pada akhirnya kita dapat mengetahui usahatani bawang merah memiliki risiko produksi dan pendapatan yang besar atau tidak, namun nilai koefisen variasi (CV) merupakan nilai yang dihasilkan dari produksi dan pendapatan hanya pada 
satu musim tanam. Sehingga tidak dapt dibandingkan, dan hanya dapat diketahui apakah kedua risiko tersebut besar atau kecil.

a. Risiko Produksi

Risiko produksi dianalisis menggunakan koefisien variasi (CV). Nilai koefisien variasi produksi yang kecil menunjukan variabilitas nilai ratarata produksi rendah. Hal ini menunjukan risiko produksi yang dihadapi petani bawang merah untuk memperoleh hasil produksi kecil dan sebaliknya. Perhitungan risiko produksi pada usahatani bawang merah dilakukan dengan analisis koefisien variasi dengan menggunakan data produksi bawang merah seperti terlihat pada tabel berikut ini.

Tabel 1. Risiko Produksi Usahatani Bawang Merah

\begin{tabular}{cc}
\hline Uraian & Risiko Produksi \\
\hline Rata - rata produksi & $1.538,37$ \\
Standar Deviasi & $1.310,49$ \\
Koefisien Variasi (CV) & 0,8518 \\
CV ( \% ) & 85,18 \\
\hline
\end{tabular}

Berdasarkan tabel 1 terlihat bahwa risiko produksi usahatani bawang merah di Kabupaten Bantul memiliki variasi yang tinggi mencapai 0,8581 atau 85,18 persen. Variasi produksi yang tinggi diakibatkan oleh variasi dalam penggunaan input (pupuk dan pestisida). Dalam menjalankan usahatani bawang merah petani satu dengan yang lainnya cenderung sama dalam penggunaan jenis benih dan pupuk baik organik maupun organik, namun dalam hal penggunaan fungisida dan insektisida petani menggunakan jenis yang cukup beragam, hal ini didasarkan pada jenis hama atau penyakit yang menyerang serta intensitas penyerangan. Variasi produksi usahatani bawang merah yang tinggi juga disebabkan karena adanya gagal panen akibat kebanjiran dan menyebabkan busuk umbi pada tahun 2010 dilokasi penelitian. Pada musim penghujan (MT I) dengan intensitas curah hujan tinggi akan menyebabkan kondisi lembab pada lahan pertanian terutama pada lahan yang drainasenya buruk, hal ini bisa mengakibatkan tanaman bawang merah mengalami busuk umbi karena tergenang air. Karena risiko gagal panen yang tinggi, petani rutin menyemprotkan insektisida, atau memberikan fungisida kalau dirasa intensitas hujan mulai meningkat, hal ini bertujuan untuk mencegah munculnya hama atau penyakit yang dapat merusak tanaman bawang merah.

b. Risiko Pendapatan

Pendapatan merupakan nilai yang diperoleh petani bawang merah dari penerimaan terhadap penjualan hasil produksi setelah dikurangi dengan biaya yang dikeluarkan dalam melakukan usahatani bawang merah. Pendapatan yang diperoleh petani seringkali tidak sesuai dengan yang diharapkan sehingga perlu diketahui risiko pendapatan. Risiko pendapatan dianalisis dengan menggunakan koefisien variasi (CV) yang hasilnya dapat dilihat pada tabel dibawah ini. 


\begin{tabular}{cc}
\hline Uraian & Risiko Pendapatan \\
\hline Rata - rata pendapatan & $3.808 .921,66$ \\
Standar Deviasi & $4.729 .533,18$ \\
Koefisien Variasi (CV) & 1.2416 \\
CV ( \%) & 124,16 \\
\hline
\end{tabular}

Berdasarkan tabel 2 menunjukan bahwa risiko pendapatan usahtani bawang merah sangat tinggi, nilai koefisien variasinya (CV) sebesar 1,2416 atau mencapai 124,16 persen. Hal ini disebabkan oleh rendahnya harga jual dan pengaruh masuknya bawang impor. Sebagian besar petani bawang merah menjual hasil panennya kepada pedagang pengumpul yang ada di tingkat desa apabila harganya sesuai karena petani tidak mau menanggung biaya pengangkutan apabila dijual langsung ke pasar, dan sistem penjualannya dilakukan oleh masing-masing petani dan tidak dijual melalui kelompok tani. Saat ini yang mempengaruhi harga jual adalah masuknya bawang impor, sehingga cenderung menurunkan harga jual. Pada kondisi seperti petani terpaksa menjual dengan harga yang ditentukan pedagang pengumpul, karena petani tidak mau menanggung kerugian apabila petani menahan hasil produksi dan tidak dijual sampai harga jualnya naik.

Adanya produk bawang impor menyebabkan posisi tawar menawar (bargainning position) petani lemah, sehingga harga jual bawang merah lebih banyak ditentukan oleh pedagang pengumpul. Namun sampai panen pada musim tanam pertama (MT I) tahun 2011 harga jual bawang merah mulai membaik dengan kisaran harga terendah Rp. 5.000,- dan tertinggi Rp. 7.500,- harga ini dirasakan oleh petani sudah layak, namun pada kenyataan dipasar harga bawang merah perkilogram bisa mencapai tiga kali lipat dari harga jual di tingkat petani, pedagang pengumpul sering berdalih di pasaran banyak bawang impor padahal ketika sampai di pasaran baik bawang impor atau bawang hasil produksi di Bantul dijual kepada konsumen dengan harga yang sama.

Berdasarkan hasil penelitian, baik risiko produksi maupun pendapatan usahatani bawang merah sangat tinggi. Bahkan persentase koefisien variasi (CV) risiko pendapatan mencapai 124,16 persen sehingga petani perlu berhatihati dalam menjalankan usahatani bawang merah agar kombinasi penggunaan input dapat mencapai output maksimum dan usahatani bawang merah mencapai efisiensi karena dengan demikian baik risiko produksi maupun risiko pendapatan dapat ditekan sehingga usahatani bawang merah dapat menghasilkan produksi yang tinggi dan pendapatan yang tinggi pula.

Perilaku petani terhadap risiko usahatani bawang merah digolongkan menjadi tiga yaitu : risk lover, risk neutral, risk averter. Fungsi produksi yang digunakan untuk menentukan nilai parameter keengganan terhadap risiko atau nilai $K(S)$ adalah fungsi produktivitas. Fungsi ini diperoleh dengan cara membagi semua input produksi atau variabel independen yakni jumlah benih, jumlah pupuk organik, jumlah pupuk phonska, jumlah fungisida padat, jumlah insektisida cair dan tenaga kerja dengan luas lahan dan diregresikan 
terhadap variabel dependen yaitu produksi ( $\mathrm{Y}$ ) tanpa memasukan lagi luas lahan. Hasil regresi fungsi produktivitas

Tabel 3. Ringkasan Model Fungsi Regresi dengan menggunakan Software SPSS Ver.20 dapat dilihat pada tabel dibawah ini.

\begin{tabular}{|c|r|r|r|r|}
\hline \multicolumn{1}{|c|}{ Model Summary } \\
\hline Model & \multicolumn{1}{|c|}{$\mathrm{R}$} & R Square & $\begin{array}{c}\text { Adjusted R } \\
\text { Square }\end{array}$ & Std. Error of the Estimate \\
\hline 1 & $.822^{\mathrm{a}}$ & .676 & .639 & .16194 \\
\hline
\end{tabular}

a. Predictors: (Constant), TKER, BENIH, PORG, FUNG, PPHO, INSE

ANOVAa

\begin{tabular}{|rl|r|r|r|r|r|}
\hline Model & \multicolumn{1}{c|}{$\begin{array}{c}\text { Sum of } \\
\text { Squares }\end{array}$} & df & Mean Square & F & \multicolumn{1}{c|}{ Sig. } \\
\hline \multirow{2}{*}{1} & Regression & 2.900 & 6 & .483 & 18.428 & $.000^{\mathrm{b}}$ \\
& Residual & 1.390 & 53 & .026 & & \\
& Total & 4.290 & 59 & & & \\
\hline
\end{tabular}

a. Dependent Variable: PROD

b. Predictors: (Constant), TK, BENIH, P_ORG, FUNGI, P_PHONS, INSEK

Hasil analisis menunjukkan $\mathrm{F}$ hitung 18,428 lebih besar dari nilai $\mathrm{F}$ tabel $(2,166)$ dan nilai signifikansinya 0,000 artinya secara bersama-sama variabel bebas berpengaruh pada produksi. Nilai koefisien determinasi $\left(R^{2}\right)$ sebesar 0,822 artinya sebesar 82,2 persen model regresi dapat dijelaskan oleh variabel variabel yang dimasukkan. Untuk mengetahui variabel apa saja yang berpengaruh terhadap produksi, dilihat dari tabel koefisien sebagai berikut:

Tabel 4. Koefisien Regresi Fungsi Produktivitas

\section{Coefficients $^{\mathrm{a}}$}

\begin{tabular}{|l|c|c|c|c|c|}
\hline Model & $\begin{array}{c}\text { Unstandardized } \\
\text { Coefficients }\end{array}$ & $\begin{array}{c}\text { Standardiz } \\
\text { ed } \\
\text { Coefficients }\end{array}$ & $\mathrm{t}$ & Sig. & Collinearity Statistics \\
\hline
\end{tabular}




\begin{tabular}{|l|r|r|r|r|r|r|r|}
\hline & \multicolumn{1}{c|}{ B } & \multicolumn{1}{c|}{$\begin{array}{c}\text { Std. } \\
\text { Error }\end{array}$} & \multicolumn{1}{c|}{ Beta } & & & Tolerance & \multicolumn{1}{l|}{ VIF } \\
\hline (Constant) & -3.213 & .996 & & -3.227 & .002 & & \\
BENIH & 1.062 & .117 & .728 & 9.100 & $.000^{* *}$ & .954 & 1.048 \\
& & & & & & & \\
P_ORG & .067 & .037 & .148 & 1.813 & $.075^{*}$ & .920 & 1.087 \\
P_PHONS & .100 & .045 & .179 & 2.215 & $.031^{* *}$ & .932 & 1.073 \\
FUNGI & -.045 & .034 & -.115 & -1.324 & $.191^{\mathrm{ns}}$ & .815 & 1.227 \\
INSEK & .045 & .023 & .189 & 1.992 & $.051^{*}$ & .680 & 1.472 \\
TK & -.123 & .059 & -.177 & -2.090 & $.041^{* *}$ & .856 & 1.168 \\
\hline
\end{tabular}

a. Dependent Variable: PROD

Model regresi yang terbentuk :

Ln $Y=-3,213+1,062 \ln$ Benih + 0,067 ln

Organik + 0,100ln Phonska - 0,045

In Fungisida $+0,045$ ln Insektisida $0,123 \ln T K+e$

Berdasarkan nilai $t$ hitung dan signifikansi dalam hasil analisis, tampak bahwa ada satu variabel input yakni jumlah benih yang berpengaruh nyata terhadap produksi bawang merah pada tingkat kesalahan 1 persen, dua variabel input yakni pupuk phonska dan tenaga kerja yang berpengaruh nyata terhadap produksi bawang merah pada tingkat kesalahan 5 persen dan dua variabel input yakni pupuk organik dan insektisida yang berpengaruh nyata terhadap produksi bawang merah pada tingkat kesalahan 10 persen, dan dilihat dari koefisien regresi, variabel jumlah benih paling berpengaruh terhadap produksi dan input inilah yang dijadikan dasar perhitungan parameter keengganan atau $K(S)$.

Berdasarkan hasil analisis regresi tersebut, maka jumlah benih berpengaruh nyata terhadap produksi bawang merah secara positif, artinya jika input bawang merah ditingkatkan sebesar 1 unit maka akan meningkatkan produksi bawang merah sebesar 1,062 unit. Demikian pula dengan variabel pupuk organik, pupuk phonska dan insektisida, ketiganya memberikan pengaruh secara positif, artinya semakin meningkat input pupuk organik, pupuk phonska dan insektisida akan meningkatkan produksi bawang merah, dimana 1 unit pupuk organik akan meningkatkan 0,67 unit, 1 unit pupuk phonska akan meningkatkan 0,100 unit dan 1 unit insektisida akan meningkatkan 0,45 unit. Hasil yang diperoleh tersebut sesuai dengan teori produksi, bahwa semakin banyak masukan akan meningkatkan output. Deteksi multikolinearitas pada suatu model dapat dilihat dari nilai Variance Inflation Factor (VIF) dan nilai Tolerance (Widarjono, 2009). Jika nilai VIF kurang dari 10 dan nilai Tolerance lebih dari 0.1, antar variabel independen tidak terjadi multikolinearitas.

Kemudian untuk menganalisis tingkat perilaku petani terhadap risiko usahatani bawang merah digunakan nilai parameter $K(S)$ yaitu keengganan 
terhadap risiko, dengan mencari nilai $K$ melalui pemilihan variabel yang paling nyata berpengaruh, dimana nilai parameter menghindari risiko (Olarinde et al, 2007) dengan kriteria perilaku menurut Moscardi and de Janvry (1977) diperoleh dari persamaan berikut :

$$
K(S)=\frac{1}{\theta}\left(1-\frac{P_{i} X_{i}}{P_{y} f_{i} \mu_{y}}\right)
$$

Keterangan :

$\theta=$ koefisien variasi dari produksi $(\theta=$ $\delta_{y} / \mu_{y}$ ) dimana $\delta_{\gamma}=$ standar deviasi dari produksi dan $\mu_{y}=$ produksi rata-rata.

$P_{y}=$ harga produk

$f_{i}=$ elastisitas produksi dari input kei (elastisitas dari input yang paling signifikan dan mempunyai kontribusi terbesar).

$X_{i}=$ jumlah input ke $-\mathrm{i}$ (jumlah input yang paling signifikan dan mempunyai kontribusi terbesar pada masing-masing responden).
$P_{x i}=$ harga input ke $-\mathrm{i}$ ( harga input yang paling signifikan dan mempunyai kontribusi terbesar pada masing-masing responden).

$\mu_{y}=$ produksi rata-rata

$K(S)=$ pengukuran parameter keengganan terhadap risiko, $S$ adalah variabel yang mempresentasikan karakteristik petani.

Input yang dipilih untuk menentukan nilai parameter K(S) adalah input yang paling signifikan dan mempunyai kontribusi terbesar terhadap produksi (Olirende et al, 2007). Hasil analisis data pada tabel 5 fungsi produktifitas menujukan pada musim tanam pertama (MT I) input yang paling signifikan dan mempunyai kontribusi terbesar adalah jumlah benih yang digunakan petani bawang merah. Uraian nilai faktor untuk menentukan parameter keengganan $K(S)$ pada musim tanam pertama dapat dilihat pada tabel 5.

Tabel 5. Nilai Faktor yang Digunakan untuk Menentukan Parameter $K(S)$

\begin{tabular}{ccccccc}
\hline Uraian & $\boldsymbol{\theta}$ & $\boldsymbol{P}_{\boldsymbol{x} i}$ & $\boldsymbol{X}_{\boldsymbol{i}}$ & $\boldsymbol{P}_{\boldsymbol{y}}$ & $\boldsymbol{f}_{\boldsymbol{i}}$ & $\boldsymbol{\mu}_{\boldsymbol{y}}$ \\
\hline MT I & 0,5876 & $\begin{array}{c}\text { harga benih } \\
\text { setiap } \\
\text { responden }\end{array}$ & $\begin{array}{c}\text { jumlah } \\
\text { benih setiap } \\
\text { responden }\end{array}$ & $\begin{array}{c}\text { harga produk } \\
\text { bawang merah } \\
\text { setiap } \\
\text { responden }\end{array}$ & 1.062 & 15,385 \\
\hline
\end{tabular}

Hasil analisis terhadap nilai parameter $K(S)$ berdasarkan kriteria perilaku menurut moscardi and de Janvry (1977) yaitu: risk lover $(0 \leq K(S)$ $\leq 0,4)$, risk neutral $(0,4 \leq K(S) \leq 1,2)$, risk averter $(1,2 \leq K(S) \leq 2,0)$, tercantum pada Tabel 5.25 berikut ini.

Tabel 6. Perilaku Petani Terhadap Risiko Usahatani Bawang Merah

\begin{tabular}{ccc}
\hline Parameter Keenganan & \multicolumn{2}{c}{ Musim Tanam I } \\
\cline { 2 - 3 } & Orang & Persen \\
\hline Risk Lover & 1 & 1,67 \\
Risk Neutral & 15 & 25 \\
\hline
\end{tabular}




\begin{tabular}{ccc}
\hline Risk Averter & 44 & 73,33 \\
\hline Jumlah & 60 & 100 \\
\hline
\end{tabular}

Tabel 6 menunjukan bahwa sebanyak 44 orang atau presentasenya sebesar 73,33 persen petani bawang merah memiliki perilaku enggan terhadap risiko (risk averter). Sebanyak 15 orang atau 25 persen petani bawang merah memiliki perilaku netral terhadap risiko (risk neutral). Dan hanya satu orang atau presentasenya sebesar 1,67 persen yang memiliki perilaku risk lover atau menyukai risiko. Secara keseluruhan petani bawang merah pada musim tanam pertama cenderung berperilaku enggan terhadap risiko (risk averter). Keengganan petani bawang merah terhadap risiko di latar belakangi oleh beberapa hal, diantaranya risiko gagal panen yang cukup tinggi, fluktuasi harga jual bawang merah yang dapat menyebabkan tingginya risiko pendapatan.

Sikap menghindari risiko usahatani bawang merah pada petani umumnya dilakukan dengan menggunakan benih bermutu tinggi, agar kualitas hasil panen baik dan produktivitasnya tinggi, secara rutin memberikan pupuk baik organik maupun anorganik kepada tanaman bawang merah hal ini bertujuan memberikan nutrisi kepada lahan agar subur dan mengurangi risiko karena lahan yang kurang subur akibat penggunaan lahan dalam waktu yang cukup lama, selain itu pemberian fungisida padat dan insektisida cair secara rutin dan intensitas penyemprotan ditingkatkan apabila terjadi serangan hama dan penyakit yang berpotensi menyebabkan risiko gagal panen. Selain itu awal pertumbuhan tanaman bawang merah sampai mencapai umur 1 - 2 minggu petani rutin melakukan kegiatan penyiraman pada pagi dan sore hari untuk menghindari tanaman mengalami kekeringan, namun setelah umur tersebut intensitas penyiraman diturunkan menjadi satu kali sehari yakni pada pagi atau sore hari saja.

Tidak menutup kemungkinan perilaku petani dalam menghadapi risiko dapat berubah-ubah dari musim tanam yang satu ke musim tanam yang lain, karena beda musim tanam berbeda pula kondisi alam yang mengharuskan petani dapat menyesuaikan dengan kondisi tersebut. Faktor yang diduga mempengaruhi perubahan perilaku petani antar musim tanam adalah kondisi musim tanam (hujan atau kemarau), pada kondisi musim yang berbeda diperlukan tindakan pemeliharaan tanaman yang berbeda pula dan jumlah input yang berbeda, serta risiko usahatani (risiko produksi, harga dan pendapatan) yang berbeda. Harga produk bawang merah yang cenderung lebih tinggi pada musim hujan dan hasil panen bawang merah yang lebih tinggi pada musim kemarau, sangat berpengaruh terhadap perubahan perilaku petani dalam menghadapi risiko.

Faktor-faktor yang diduga mempengaruhi perilaku petani terhadap risiko usahatani bawang merah atau parameter keengganan terhadap risiko $K(S)$ adalah luas lahan usahatani bawang merah, umur petani, pendidikan petani, pengalaman usahatani, jumlah 
tanggungan keluarga, pendapatan usahatani bawang merah, dan pendapatan luar usahatani bawang merah. Hasil analisis faktor-faktor yang mempengaruhi perilaku petani terhadap risiko usahatani bawang merah dapat dilihat pada tabel 7 berikut ini.

Tabel 7. Faktor-faktor yang Mempengaruhi Perilaku Petani terhadap Risiko Usahatani Bawang Merah

\begin{tabular}{ccccccc}
\hline Variabel & $\begin{array}{c}\text { Tanda } \\
\text { Harapan }\end{array}$ & $\begin{array}{c}\text { Koefisien } \\
\text { Regresi }\end{array}$ & $\begin{array}{c}\text { Standar } \\
\text { Error }\end{array}$ & t-hitung & Prob & Signifikan \\
\hline & $+/-$ & - & & - & & $* * *$ \\
C & & 4.336942 & 0.901809 & 4.809156 & 0.0000 & \\
L_LAHAN & - & 0.062295 & 0.047976 & 1.298460 & 0.1999 & $\mathrm{~ns}$ \\
U_PETANI & - & 0.485244 & 0.161631 & 3.002178 & 0.0041 & $* * *$ \\
PNDK & - & 0.268962 & 0.108821 & 2.471605 & 0.0168 & $*$ \\
P_USTAN & - & 0.058241 & 0.066557 & 0.875060 & 0.3856 & $\mathrm{~ns}$ \\
JMLTGKLG & - & 0.004092 & 0.065578 & 0.062398 & 0.9505 & $\mathrm{~ns}$ \\
PENDUSTAN & - & 0.072568 & 0.033379 & 2.174101 & 0.0343 & $* *$ \\
PENLUSTAN & - & 0.064502 & 0.030656 & 2.104068 & 0.0402 & $*$ \\
\hline R-squared & & 0.526767 & $* * *$ & $:$ & Signifikan pada tingkat $1 \%$ & \\
F-statistic & & 8.268924 & $* *$ & $:$ & Signifikan pada tingkat $5 \%$ & \\
& & & $*$ & $:$ & Signifikan pada tingkat $10 \%$ & \\
& & & ns & $:$ & Tidak Signifikan & \\
\hline
\end{tabular}

Nilai koefisien determinasi $\left(\mathrm{R}^{2}\right)$ sebesar 0,5267 atau 52,67 persen. Hal ini berarti 52,67 persen variasi dari perilaku petani terhadap risiko usahatani bawang merah dapat dijelaskan oleh variasi variabel independen dalam model. Nilai $\mathrm{F}$ hitung pada musim tanam pertama sebesar 8,26 lebih besar dari $\mathrm{F}$ tabel $(2,166)$. Sehingga variabel independen secara bersama-sama berpengaruh berpengaruh nyata terhadap variabel dependen. Sehingga pada musim tanam tersebut, perilaku petani terhadap risiko dipengaruhi oleh karakteristik sosial ekonomi petani secara bersama-sama meliputi umur petani, pendidikan petani, pendapatan usahatani bawang merah, dan pendapatan luar usahatani bawang merah. Sedangkan variabel luas lahan, pengalaman usahatani dan jumlah tanggungan keluarga tidak berpengaruh nyata (non significant) terhadap perilaku petani terhadap risiko. Adapun penjelasan pengaruh masing-masing variabel independen terhadap perilaku petani atau parameter $K(S)$ atau keenganan terhadap risiko usahatani bawang merah adalah sebagai berikut :

1. Luas lahan

Luas lahan rata-rata petani bawang merah di Kabupaten Bantul 1,7245 hektar dengan luas lahan maksimal 0,65 hektar dan luas tanam minimal 0,02 hektar. Luas lahan tidak berpengaruh nyata dan positif terhadap parameter keengganan risiko pada musim tanam pertama. Berarti dengan menambah atau mengurangi luas lahan tidak akan mengurangi keenggenan terhadap risiko atau petani bersikap netral terhadap risiko. 
Usahatani bawang merah memerlukan modal yang besar, luas lahan minimal yang dapat memberikan pendapatan positif adalah 0,02 hektar. Sehingga dengan semakin luas lahan yang ditanami bawang merah diharapkan memberikan hasil yang lebih besar. Dengan sendirinya petani akan semakin berani terhadap risiko jika luas lahannya semakin luas.

2. Umur petani

Umur merupakan faktor penting yang mempengaruhi sikap petani untuk menerima hal - hal baru karena umur menentukan kinerja petani. Umur petani bawang merah dilokasi penelitian ratarata 47,7 tahun dengan umur termuda 24 tahun dan tertua 78 tahun. Hasil uji t terhadap koefisien regresi umur menunjukan berpengaruh nyata terhadap parameter keengganan terhadap risiko " $K(S)$ ". Artinya petani dengan umur lebih muda dan petani berumur tua dengan pengalaman dan ketrampilan yang lebih banyak mempengaruhi kengganannya terhadap risiko usahatani bawang merah. Petani yang berumur tua lebih bersikap hatihati, karena dengan pengalaman yang dimiliki mampu membaca peluang yang ada dan enggan menanggung risiko. Hasil ini sesuai dengan pendapat Astuti (2002); Ihsanudin (2006); Imelda (2008) yang meyatakan bahwa semakin bertambah umur petani maka semakin meningkat perilaku keengganan terhadap risiko. Kemampuan kerja petani sangat ditentukan oleh umur petani yang akan mempengaruhi kemampuan fisik dalam bekerja. Petani yang lebih muda tentunya akan memiliki fisik yang lebih kuat dibandingkan petani yang sudah tua. Petani pada kategori muda atau produktif akan lebih mudah menerima inovasi baru dibandingkan petani yang lebih tua, karena petani pada ketgori umur muda lebih senang menanggung risiko, walaupun pengalaman berusahatani dari petani muda masih sedikit dibandingkan petani yang yang lebih tua. Untuk mengimbangi kekuranagan ini biasanya petani muda lebih dinamis, sehingga cepat mendapat pengalaman baru yang berguna bagi pengembangan usahatani bawang merah kedepannya.

3. Pendidikan Petani

Pendidikan formal petani bawang merah dilokasi penelitian rata-rata 9,57 tahun dan pendidikan terendah 6 tahun dan pendidikan tertinggi 17 tahun. Jadi rata-rata petani sampel sudah menamatkan Sekolah Lanjutan Tingkat Pertama (SLTP). Hasil uji t terhadap koefisien regresi pendidikan petani berpengaruh nyata terhadap parameter keengganan terhadap risiko " $K(S)$ ". Artinya semakin tinggi tingkat pendidikan petani, semakin berani menanggung risiko. Hal ini sejalan dengan hasil penelitian Istiyanti yang menunjukan bahwa petani berpendidikan tinggi berperilaku lebih berani menanggung risiko daripada petani yang berpendidikan rendah. Dengan pendidikan seseorang akan mendapat pengetahuan, dari pengetahuan yang didapat seseorang akan lebih mudah menerima dan mempelajari inovasi baru, demikian dengan petani yang memiliki pendidikan lebih tinggi maka cenderung akan lebih menerima hal baru yang mana akan meningkatan taraf hidup menjadi lebih baik.

4. Pengalaman Usahatani 
Pengalaman petani dalam usahatani bawang merah akan membuat petani menjadi lebih banyak tahu tentang segala sesuatu yang berhubungan dengan usahatani bawang merah. Pengalaman usahatani petani bawang merah dilokasi penelitian rata-rata 19,6 tahun dan pengalaman terendah 5 tahun dan paling lama 52 tahun. Hasil uji t terhadap koefisien regresi pengalaman usahatani tidak berpengaruh nyata terhadap parameter kenggenan terhadap risiko " $K(S)$ ". Artinya semakin lama pengalaman usahtani membuat petani semakin berani menanggung risiko. Hal ini tidak sejalan dengan penelitian Juarini (2003) yang menyatakan bahwa semakin lama pengalaman usahatani semakin enggan terhadap risiko.

5. Jumlah Tanggungan Keluarga

Jumlah tanggungan keluarga petani bawang merah rata-rata 3 orang dengan jumlah anggota keluarga paling banyak 9 orang. Hasil uji t terhadap koefisien regresi jumlah tanggungan keluarga tidak berpengaruh nyata terhadap parameter kenggenan terhadap risiko " $K(S)$ “.. Hal ini dapat dijelaskan bahwa usahatani bawang merah sebagai mata pencaharian pokok, tetapi mereka juga mempunyai usaha sampingan untuk menghidupi keluarga misalnya dengan beternak untuk menunjang ekonomi keluarga. Sehingga kebutuhan keluarga bisa tercukupi tidak hanya dari usahatani bawang mreah tetapi juga dari luar usahtani. Hasil ini sejalan dengan penelitian Astuti (1992) bahwa jumlah tanggungan keluarga tidak berpengaruh terhadap perilaku petani. Tanggungan keluarga merupakan beban bagi petani sehingga menyebabkan petani enggan untuk mengambil risiko karena petani berpendapat jika terjadi kegagalan dalam berusahatani maka akan mengurangi pendapatan dan kemampuan petani untuk menghidupi anggota keluarganya, namun hasil analisis tidak signifikan, sehingga menunjukan tidak ada pengaruh antara jumlah tanggungan keluarga petani dengan perilaku terhadap risiko.

6. Pendapatan Usahatani Bawang Merah

Pendapatan rata-rata usahatani bawang merah dilokasi penelitian sebesar Rp. 3.808.921,- dan pendapatan terendah Rp. 312.325,- dan pendapatan tertinggi Rp. 32.491.416. Hasil uji t terhadap koefisien regresi pendapatan usahatani bawang merah berpengaruh nyata terhadap parameter kenggenan

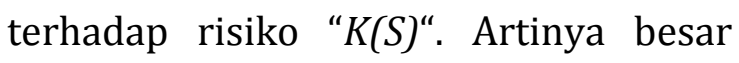
kecil pendapatan dari usahatani bawang merah berpengaruh terhadap perilaku petani terhadap risiko. Apabila pendapatan usahtani bawang merah naik petani akan cenderung akan berhati-hati dalam menjalankan kegiatan usahataninya, dengan kata lain petani akan semakin enggan terhadap risiko.

7. Pendapatan Luar Usahatani Bawang Merah

Pendapatan rata-rata luar usahatani bawang merah dilokasi penelitian sebesar Rp. 15.430.356.43 dan pendapatan terendah Rp. 1.200.000,dan pendapatan tertingi Rp. 93.220.000. Hasil uji t terhadap koefisien regresi pendapatan luar usahatani bawang merah berpengaruh nyata terhadap parameter kenggenan

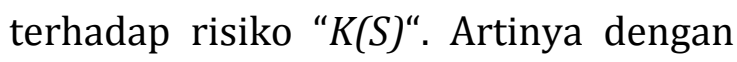
bertambahnya pendapatan luar usahatani maka akan mengurangi keenganan petani terhadap risiko, atau 
dengan kata lain petani semakin berani terhadap risiko. Jika pendapatan luar usahatani bawang merah naik petani cenderung akan berani menanggung risiko dengan harapan pendapatan yang diperoleh besar, dan apabila merugi petani masih memiliki pendapatan luar usahatani bawang merah untuk menutup semua kerugian tersebut, tetapi kalau sebaliknya pendapatan laur usahatani bawang merah kecil maka petani tidak berani menanggung risiko dan akan memaksimalkan usahatani miliknya.

Komoditas bawang merah merupakan salah satu komoditas hortikultura yang bersifat komersial, sehingga hipotesis yang muncul pada awal penelitian ini adalah perilaku petani terhadap usahatani bawang merah bersifat risk lover atau menyukai risiko. Namun, berdasarkan hasil penelitian parameter keengganan terhadap risiko yang dihitung dengan pendekatan Moscardi dan de Janvry berdasarkan input jumlah benih menunjukan sebagian besar petani bawang merah dilokasi penelitian menolak risiko atau risk averter. Hal ini karena petani berusaha meminimumkan input untuk meminimumkan biaya produksi, selain itu petani tidak mementingkan produksi dan penerimaan yang tinggi melainkan telah puas dengan penerimaan yang ada karena sudah mampu mencukupi kebutuhan pokok dirinya dan keluarga. Perilaku risk averter juga terkait dengan luas lahan yang relatif sempit dan terpencar serta modal yang terbatas, sehingga petani berasumsi walaupun penghasilannya kecil yang penting usahatani bawang merah tetap bisa dijalankan, dan kebutuhan keluarga terpenuhi. Berdasarkan perhitungan nilai koefisien variasi (CV) baik risiko produksi maupun pendapatan tergolong tinggi. Sehingga petani sangat berhatihati dalam menjalankan usahatani bawang merah, selain itu kondisi alam yang tidak menentu saat ini membuat petani semakin berhati-hati, sehingga untuk menekan risiko produksi dan pendapatan yang lebih besar, petani bawang merah selalu menanam bawang merah secara tumpang sari dengan tanaman cabe. Hal ini hendak menjelaskan bahwa petani bawang merah sebenarnya tidak berani menanggung risiko (risk averter).

\section{SIMPULAN}

Baik risiko produksi maupun risiko pendapatan usahatani bawang merah di Kabupaten Bantul tergolong tinggi. Berdasarkan input jumlah benih, penentuan parameter keenggenan terhadap risiko $K(S)$ menghasilkan petani bawang merah yang menolak risiko (risk averter) lebih banyak dari petani yang berani menanggung risiko (risk lover), dan bersikap netral terhadap risiko (risk neutral), dan faktor-faktor yang mempengaruhi perilaku petani terhadap risiko usahatani bawang merah adalah umur petani, pendidikan, pendapatan usahatani bawang merah dan pendapatan luar usahatani bawang merah.

\section{DAFTAR PUSTAKA}

Anonim. 2005. Peraturan Presiden Republik Indonesia Nomor 7 Tahun 2005, Tentang : Rencana Pembangunan Jangka Menengah Nasional Tahun 2004 - 2009. Jakarta : CV. Eka Jaya. 
Astuti, A. 1992. Analisis Risiko dan Perilaku Petani Bawang Putih di Kabupaten Bantul Yogyakarta. Tesis Ekonomi Pertanian Pasca Sarjana UGM. Yogyakarta.

Binswanger HP, Sillers DS (1990). Risk aversion and credit constraints in farmer's decision. J. Dev. Stud., 20: 5-21.

Chen, K.Z., K.D. Meilke., and C. Turvey., 1999"Income Risk and Farm Consumption Behavior". Agricultural Economics. 20:173183.

Debertin, D.L. 1986. "Agricultural Production Economics". New York : Macmillan Publishing Company.

Doll, J.P. and F, Orazem. 1984. "Production Economics, Theory With Application". New York : John Willey and Sons Inc.

Ellis, Frank. 2003. Peasant Economics (Petani Gurem : Rumah Tangga Usahatani dan Pembangunan Pertanian). Diterjemahkan oleh Adi Sutanto dkk. Bayu Media dan UMM Press.

Greene, W.H. 1993. Econometric Analysis, Second Edition. New York : Macmillan Publishing Company.

Gujarati, D. 1988. Ekonometrika Dasar. Jakarta : Erlangga.

Ihsanudin. 2006. Perilaku Petani terhadap Risiko dalam Usahatani Tembakau di Kabupaten Magelang. Tesis Program Pasca Sarjana, Fakultas Pertanian. UGM. Yogyakarta.

Imelda. 2008. Analisis perilaku petani terhadap risiko usahatani lidah bauaya di Pontianak. Tesis
Program Pasca Sarjana, Fakultas Pertanian, UGM. Yogyakarta.

Juarini. 2003. Perilaku Ekonomi Petani

Terhadap Risiko Usahatani di Lahan Pantai Kabupaten Kulon Progo. Disertasi Ekonomi Pertanian. Program Pasca Sarjana, Fakultas Pertanin, UGM.

Just, R.E. and R.D.Pope . 1979. "Production Function Estimation and Related Risk Consideration". American Journal of Agricultural Economics, 6(2).

Maddala.G.S., 1992. Introduction to

Econometric. Second's Eds, New Jersey : Prentice Hall International, Inc.

Moscardi, E. and Alain de Janvry.1977.Attitudes toward risk among Peasants: An Econometrics Approach. American Journal of Agricultural Economics. 50 Vol 59. No. 4(Nov., 1977), pp. 257-277.

Olarinde, L. O., V. M.Manyong and J.O. 2007. Attitude Towards Risk Among Maize Farmer In The Dry Savana Zone of Nigeria: Some Prospective Policies for Improving Food Production. African Journal Agricultural Research Vol.2 (8)(August) pp.399-408.

Pappas, J.L., dan Hirschey, M. 1995. Ekonomi Manjerial. Jakarta : Bina Rupa Aksara.

Pindyck, R.S. and D.L. Rubinfeld. 1991. Econometric Models and Economic Fore Casts. New York : Mc GrawHill.

Soekartawi. 2002. Prinsip dasar Ekonomi Pertanian : Teori dan Aplikasi. 
Edisi Revisi. Jakarta : Raja

Grafindo Persada.

Widarjono, A. 2009. Ekonometrika: Teori

dan Aplikasi untuk Ekonomi dan Bisnis.

Edisi Kedua, Cetakan Pertama.

Yogyakarta : Ekonisia. 